\title{
The role of visual and olfactory plant cues in aphid behaviour and the development of non-persistent virus management strategies
}

\author{
M. L. Schröder, 1 \\ R. Glinwood, 2 \\ R. Ignell, 3 \\ K. Krüger, $1, *$
}

Phone +27124204619

Email kkruger@zoology.up.ac.za

1 Department of Zoology and Entomology, University of Pretoria, Private Bag X20, Pretoria, 0028, South Africa

2

Department of Crop Production Ecology, Swedish University of

Agricultural Sciences, Uppsala, Sweden

3 Unit of Chemical Ecology, Department of Plant Protection

Biology, Swedish University of Agricultural Sciences, Alnarp, Sweden

\section{Abstract}

Non-persistent viruses are transmitted by aphids in short feeding probes during the initial stages of aphid host plant selection behaviour. To control the transmission of these viruses, farmers rely on pesticides and cultural control practices, with varying success rates. As a result, there is a need for novel management practices that are more robust and specific to reducing aphid landing rates in crops. Aphid-plant-virus interactions involve a number of behaviours and processes to ensure survival of the insect vector and virus. So far, virus management tactics focused on reducing immigrating aphids in crops have emphasized the manipulation of visual 
rather than olfactory stimuli. An improved understanding of the synergistic or additive effects in which aphids use visual and olfactory stimuli to locate host plants could be used to improve on current non-persistent virus management tactics and develop novel strategies. The aim of this review is to evaluate current understanding of aphid vector behaviour and the ways that these behaviours have been exploited to develop management strategies, and to identify areas of research needed to further improve virus management.

\section{Keywords}

Aphid vector

Non-persistent plant viruses

Colour vision

Aphid olfaction

Management strategies

Handling Editor: Heikki Hokkanen.

\section{Introduction}

Aphids are responsible for the transmission of more than $50 \%$ of insecttransmitted plant viruses, including persistent and non-persistent viruses (Nault 1997). Virus transmission occurs by immigrating aphids in search of new host plants before colonizing the plants or reaching high population numbers. Persistent viruses require acquisition periods of hours to days and have a latent period of several hours to days before transmission occurs $(\mathrm{Ng}$ and Perry 2004). Consequently, they are mostly transmitted by aphid species that colonize the crops (Fereres and Moreno 2009). In contrast, non-persistent viruses can be acquired (uptake of virus from infected source) and inoculated (delivery of virus to site of infection) within short feeding times of seconds to minutes, and aphids are only able to retain these viruses for a relatively short time (Boquel et al. 2011; Bradley 1954; Fereres and Raccah 2015; Katis and Gibson 1985 ). For example, Rhopalosiphum padi (L.) retains two strains of Potato virus Y (PVY) for up to $6 \mathrm{~h}$ and Myzus persicae (Sulzer) for up to $4 \mathrm{~h}$ (Katis and Gibson 1985). Retention time varies not only between aphid species but between virus strains as well. For example, $M$. persicae was able to transmit PVY $\mathrm{W}$ to four plants and PVY ${ }^{\mathrm{NTN}}$ to seven plants when allowed to feed on each of ten plants for $2 \mathrm{~min}$ in succession 
(Kostiw and Trojanowska 2011 ). The most important aphid-transmitted viruses and their transmission mechanisms are reviewed by $(\mathrm{Ng}$ and Falk ( 2006), Ng and Perry (2004) and Whitfield et al. ( 2015). The most important family of non-persistent viruses is the Potyviridae, which contains the highest number of aphid-transmitted virus species (Nault 1997; Ng and Perry 2004 ). Transient aphid species that land and probe but do not colonize the crop play an important role in the epidemiology of non-persistent viruses (Fereres and Moreno 2009; Halbert et al. 1981; Tomlinson 1987). For example, Katis et al. (2006) observed that the majority of aphid species able to transmit Zucchini yellow mosaic virus (ZYMV) were transient species that do not colonize zucchini (Cucurbita pepo L., Cucurbitaceae). Although many of these transient species do not transmit ZYMV efficiently, they may occur in high numbers (Katis and Gibson 1985; Katis et al. 2006), making them important virus vectors.

Aphid populations and the incidence of persistently transmitted viruses can be controlled by insecticide applications (Boiteau and Singh 1999; Makkouk and Kumari 2001, 2009), and by combining insecticides with aphid forecasting satisfactory results can be obtained (Parker et al. 2002). However, in the case of non-persistent virus transmission, management is not that simple. Current control practices are insufficient (Radcliffe and Ragsdale 2002; Robert 1992 ), and additional management practices that reduce the incidence of non-persistent viruses are needed. In the development of these practices, it is important to acknowledge that both the aphid and the virus rely on the plant for survival (Mauck et al. 2012). However, plant viruses are dependent on their insect vectors to disperse to new hosts (Mauck et al. 2012; Powell et al. 2006 ). Only after plant contact is made does host recognition occur, and the plant may be rejected at this stage in search of a new or more suitable one (Powell et al. 2006). Non-persistently and persistently transmitted viruses require different aphid behaviours for transmission and therefore interact differently with the plant and the insect vector to ensure dispersal and survival. In the case of non-persistent viruses, increased aphid activity favours virus transmission, but in the case of persistent viruses, host acceptance is required before the virus is transmitted. Thus, the relationship between plant, insect and pathogen involves a number of interactions to ensure survival of both vector and virus. This review evaluates current understanding of aphid vector behaviour and the ways that these behaviours have been exploited to develop novel management strategies, and identifies areas of research needed 
to further improve the development of virus management strategies.

\section{Aphid polymorphism and flight behaviour}

The high degree of polymorphism displayed by aphid life cycles plays an important role in the spread of non-persistent plant viruses (Blackman and Eastop 2000; Dixon 1977; Swenson 1968 ). Two types of overwintering strategies can be distinguished, holocyclic and anholocyclic. Holocyclic populations produce winged migrants (gynoparae), which migrate to primary host plants (woody plants), where they produce sexual morphs (oviparae) that mate and oviposit. In spring, the eggs hatch and, after one or two generations, parthenogenetic alate (winged) migrants (virginoparae) are produced. These migrants are able to disperse over long distances to the secondary host plants (herbaceous plants, including many agricultural crops). Once migrated to the secondary host plant, the virginoparae are able to acquire and subsequently transmit non-persistent viruses (Dixon 1971; Dixon and Glen 1971; Leather 1993; Swenson 1968). After settling on a host plant, they produce apterae. However, when the colony becomes crowded or plant quality declines, the colony produces virginoparae that migrate in search of another host plant (Müller et al. 2001). Anholocyclic populations overwinter on secondary host plants and do not produce sexual morphs, but alternate between alate and apterous (wingless) parthenogenetic morphs throughout the year (Dixon 1971 ; Dixon and Glen 1971; Leather 1993 ). Anholocyclic aphids are thus able to transmit non-persistent viruses throughout the year. Therefore, both anholocyclic and the spring and summer migrants of holocyclic aphids play an important role in the spread of non-persistent viruses.

Alate aphids that have acquired non-persistent viruses are able to disperse into regions where virus inoculum is low, causing unexpected virus outbreaks, and several virus epidemics have been attributed to long-range dispersal of aphids (Irwin et al. 1988). For example, in Eastern Canada, Barley łyellow Đdwarf $\forall$ virus (BYDV) incidence is generally low. However, in the autumn of 1982, BYDV incidence in winter wheat and barley increased dramatically, reaching levels of up to $100 \%$ (Paliwal and Comeau 1984). The dramatic increase was associated with a sudden influx of two cereal aphids, $R$. padi and $R$. maidis (Fitch), with steady south-westerly winds (Paliwal and Comeau 1984). However, Loxdale et al. (1993) argue that it is possible that many of the virus outbreaks attributed to long-distance flight in North America could be due to aphids overwintering anholocyclically. In southern England, cereal aphids are able to survive temperatures as low as $-7{ }^{\circ} \mathrm{C}$ (Williams and Wratten 1987). In 
sheltered environments, such as grass tussocks and hedgerows, aphids are protected from the wind, rain and snow in winter and they may survive and colonize cereal crops much sooner in spring than migrants from the primary host (Dean 1974; Williams and Wratten 1987). Therefore, anholocyclic populations may be more important in virus spread than holocyclic populations overwintering as eggs, especially early in the season before spring migrations from holocyclic populations take place. For this reason, increasing winter temperatures associated with climate change in certain regions are likely to lead to increased frequency and severity of some viruses, such as BYDV.

Migratory aphids undergo successive behavioural steps of pre-flight, flight and alighting to find and settle on a new host plant (Kring 1972). Shortly after the final moult (pre-flight period), winged aphids become positively phototactic and take off from the plant, orienting themselves upwards into the sky to initiate their dispersal flight (Kennedy and Booth 1963). Flight duration varies between species and is dependent on finding a suitable host (Kring 1972). For example, flight duration in Aphis fabae Scopoli, varies between 7 and 234 min before settling on a plant (Kennedy and Booth 1963 ). However, aphids are able to take off and resume a second flight, followed by several bouts of short flights until exhaustion occurs (Kennedy and Booth 1963 ). Therefore, the flight duration required for an aphid to become responsive to a target and land on it is shorter than the total flight duration till exhaustion occurs (Kennedy and Booth 1963). This gives the aphid a chance of locating a plant even if it landed on a poor or unsuitable host, favouring the spread of non-persistent viruses.

\section{Current control strategies of non-persistent viruses and their limitations}

Commercial farmers rely mainly on the application of insecticides to reduce transmission of non-persistent viruses (Perring et al. 1999; Robert et al. 2000 ). However, due to the manner in which aphids transmit non-persistent viruses, insecticides are not always effective in reducing transmission (Boiteau et al. 1985; Desbiez and Lecoq 1997; Lowery and Boiteau 1988). Growers are also advised to make use of cultural control methods aimed at reducing virus inoculum in the growing region and reducing the number of potential vectors entering their crops (Boiteau et al. 1985; Fereres 2000 ; Lowery and Boiteau 1988; Radcliffe and Ragsdale 2002). These may include using only certified virus-free seed, practicing stringent weed control around 
fields and roguing (removing virus-infected plants) (Desbiez and Lecoq 1997; Radcliffe and Ragsdale 2002; Sastry 2013; Tomlinson 1987). It is also recommended that crop species that are hosts for similar viruses are not cultivated in close proximity (Radcliffe and Ragsdale 2002; Tomlinson 1987 ). Spatial isolation is recommended for crops such as potato that is produced for either seed or ware potatoes. Commercial ware potatoes should not be planted in the same region as seed potatoes because cultivation of both may increase virus inoculum dramatically, since disease tolerances of ware potatoes are much lower than for seed potatoes (Radcliffe and Ragsdale 2002 ). Growers should also avoid continuous planting of crops that can be produced year round, such as celery and lettuce, to reduce the risk of Celery mosaic virus and Lettuce mosaic virus being transmitted from older infected crops to newly planted crops within the area (Sastry 2013; Wisler and Duffus 2000 ). The use of crop borders (planting a non-virus host plant around the main crop) may further reduce the incidence of non-persistent viruses in agricultural crops due to aphids landing in high numbers at the edge of the field, and the crop border acting as a virus sink. Aphids probing the crop border lose their ability to further transmit the virus before entering the main crop (Hooks and Fereres 2006).

\section{Insecticides and mineral oils}

Insecticides do not reduce non-persistent virus incidence by directly preventing infection in crops such as Zucchini, melon and potatoes, but are rather aimed at reducing the aphid population (Boiteau and Singh 1999; Desbiez and Lecoq 1997; Robert et al. 2000; Tomlinson 1987). Insecticides do not take immediate effect and, due to the fast transmission rate of non-persistent viruses, aphids are able to transmit virus before being killed by the insecticide (Gibson et al. 1982; Radcliffe and Ragsdale 2002). No reduction in ZYMV incidence was found in musk melon (Cucumis melo L., Cucurbitaceae) treated with pyrethroids (Perring and Farrar 1993 ). Pyrethroids, such as deltamethrin, on the other hand, can assist in the reduction in non-persistent virus spread (Gibson et al. 1982). This may be due to toxic effects occurring rapidly, paralysing the aphids before virus transmission or acquisition can occur (Gibson et al. 1982). However, the efficiency of pyrethroids has been found to vary between aphid species and clones (Gibson et al. 1982; Lowery and Boiteau 1988).

Aphid behaviour can be modified by insecticides which could potentially play a role in non-persistent virus transmission (Boquel et al. 2015; Roberts et al. 
1993 ). At sub-lethal doses pyrethroids may enhance virus spread due to a repellent effect, causing an increase in aphid activity (Gibson et al. 1982; Robert et al. 2000; Roberts et al. 1993). In addition, the influence of insecticides on aphid behaviour may vary between different types of insecticides and aphid species. Lambda-cyhalothrin, a contact insecticide, increased the number of Macrosiphum euphorbiae (Thomas), leaving the plant, reduced the number of $R$. padi probing treated leaflets but had no effect on A. fabae (Boquel et al. 2015 ). In contrast, dimethoate, a systemic insecticide, had no effect on aphid behaviour (Boquel et al. 2015). Although some insecticides are able to modify aphid behaviour, they are unlikely to contribute towards the reduction in non-persistent virus spread, such as CMV and PVY due to their slow-acting nature, lack of residual effect and varying efficiency between aphid species (Boquel et al. 2015; Gibson et al. 1982; Lowery and Boiteau 1988). However, insecticides still remain the main management tactic for the control of non-persistently transmitted viruses (Radcliffe and Ragsdale 2002; Robert et al. 2000).

Mineral oils can reduce the incidence of non-persistent viruses and are used commercially in Europe and Israel (Boiteau and Singh 1982; Simons and Zitter 1980). They have been shown to delay the onset of non-persistent virus infestation in pepper (Capsicum annuum L., Solanaceae), and once plants are infected can reduce further spread within fields (Simons and Zitter 1980). In laboratory experiments, mineral oil also reduced acquisition and inoculation of PVY between Nicotiana plants by M. persicae (Powell 1992). Simons et al. (1977) found that contact between the aphid labium and the oil was sufficient to reduce transmission by causing an increase in the pre-probing time. However, Powell (1992) did not find any change in stylet plant penetration activity and PVY transmission. This suggests that the oil may disrupt the interaction between the virus, plant cell and aphid foregut (Bradley 1963 ; Powell 1992 ). Recently, it has been demonstrated that mineral oils reduces PVY acquisition by aphids (Boquel et al. 2013).

The ability of mineral oils to reduce non-persistent virus incidence varies with inoculation potential (the percentage of infected plants in a field), crop density, application method and concentration of the mineral oil used (Boquel et al. 2013; Simons et al. 1977; Simons and Zitter 1980). However, the effectiveness of oils diminishes with an increase in inoculation potential (Simons et al. 1977). Therefore, oils are considered to be most effective in crops produced at high altitude where aphid activity and abundance is low 
(Simons and Zitter 1980). In addition, mineral oils are less effective in crops planted at low densities such as watermelon (Citrillus lanatus (Thinb.), Cucurbitaceae) compared with crops planted at high densities such as pepper (Simons and Zitter 1980). An even coverage of the oil on the leaves is important to obtain maximum results (Simons and Zitter 1980). However, the use of mineral oils to reduce spread of non-persistent viruses is limited due to potential adverse effects on the crop (Simons et al. 1977). Mineral oils can be phytotoxic (Kalleshwaraswamy et al. 2009; McKenna et al. 1995 ). For example, mineral oil sprays caused speckling damage in Kiwi fruit when applied more than 2 weeks after fruit set (McKenna et al. 1995). In addition, it is only effective for several days after application (Boquel et al. 2013).

\section{Crop borders}

Farmers are advised to use a number of preventative cultural control methods to reduce non-persistent virus incidence (Radcliffe and Ragsdale 2002). These include using certified seed, rouging and removing weeds to reduce source inoculum, as well as planting in geographically isolated areas. A number of reviews have covered this topic (Radcliffe and Ragsdale 2002; Robert et al. 2000; Sastry 2013; Tomlinson 1987; Weidemann 1988). Although these are suitable preventative methods, they need to be used on a regional scale to be effective, and they do not always achieve acceptable levels of control (Perring and Farrar 1993; Sastry 2013). Crop borders, an additional cultural control tactic that relies on the manipulation of vector biology, have been proposed for the control of non-persistent viruses (Hooks and Fereres 2006).

Aphids tend to land in high numbers at field edges due to their sensitivity to long wavelength light and the contrast in light reflected from the soil and the plants (Broadbent et al. 1951; Minks and Harrewijn 1988). Planting a crop around the main crop displaces the edge of the main field, reducing the number of aphids landing in the main crop (Hooks and Fereres 2006). After landing on a plant, aphids evaluate the leaf surface characteristics and briefly probe the epidermis, ingesting small amounts of leaf sap, which is evaluated by the hypopharyngeal organ in the gut (Powell et al. 2006). During this initial probing, aphids are able to transmit non-persistent viruses (Bradley 1954 ; Broadbent et al. 1951). Therefore, planting a non-virus host plant (a plant not affected by a virus) as a crop border causes aphid vectors to lose their ability to transmit the virus before entering the field proper (Broadbent et al. 1951; Hooks and Fereres 2006 ). 
Several studies have evaluated the efficacy of crop borders for reducing virus incidence, with varying results (DiFonzo et al. 1996; Hooks and Fereres 2006). A reduction in PVY incidence was found in seed potatoes planted with crop borders in Minnesota and North Dakota (DiFonzo et al. 1996). A survey on the use of crop borders in these states in 2005 revealed that, on average, less than $0.06 \%$ of 152 seed lots entered in seed certification programmes in 2004 were rejected due to PVY infection in summer. In winter, $97 \%$ of the seed lots produced with crop borders, compared to $54 \%$ of seed lots grown without crop borders, passed the seed certification test (Olson et al. 2005). However, factors such as the pattern of virus spread, height of the barrier crop when maximum risk of infection occurs and the extent of competition between the barrier and the protected crop may affect the outcome of crop borders as a control strategy against non-persistent viruses (Fereres 2000).

Various plant species have been identified as crop border plants, and their effectiveness in reducing non-persistent virus incidence varies between studies. In potatoes planted with borders of wheat (Triticum aestivum L., Poaceae), sorghum (Sorghum bicolor L., Poaceae), rye (Lolium perenne L., Poaceae), soybean (Glycine $\max$ (L.), Fabaceae) and potato, the reduction in PVY incidence in potato fields was similar for all crop border plant species used (DiFonzo et al. 1996; Olson et al. 2005). Although potato was as effective as soybean in reducing PVY incidence in potato crops, it is not advisable to use potato as a crop border plant because it is a virus host. Some variation in the reduction in virus incidence between crop border plant species has been observed (Damicone et al. 2007). Crop borders of sorghum were effective in reducing Watermelon mosaic virus (WMV) and Papaya ringspot virus-W (PRSV-W) in pumpkin (Cucurbita pepo L., Cucurbitaceae)

(Damicone et al. 2007). However, peanut (Arachis hypogaea L., Leguminosae), soybean and maize (Zea mays L., Poaceae) did not affect WMV and PRSV-W transmission (Damicone et al. 2007). Wheat was effective in reducing WMV-1 and WMV-2 in muskmelon crops when planted as a crop border (Toba et al. 1977). In some cases, crop borders have an adverse effect on the main crop. Although Swiss chard reduced WMV-1 and WMV-2 incidence, it caused major yield loss by stunting muskmelon growth and was a host of potato leafhopper, Empoasca fabae (Harris) (Hemiptera: Cicadellidae), a pest on muskmelon (Toba et al. 1977). Therefore, the effect of plant species on insect vector behaviour and thus disease incidence, as well as on the crop to be protected, should be considered when selecting a crop border plant. In addition, crop borders should be compatible with current 
production practices to avoid additional production costs (DiFonzo et al. 1996; Radcliffe and Ragsdale 2002 ).

Crop borders may act as a virus sink, barrier crop or trap crop (Hooks and Fereres 2006). According to the virus sink hypothesis (Hooks and Fereres 2006 ), aphids land on the border crop first (a non-virus host) and, when probing the plant during initial host evaluation, lose their potential to transmit non-persistent viruses before re-alighting and landing in the main crop (DiFonzo et al. 1996; Toba et al. 1977). Tall barrier crops are thought to reduce the number of aphids landing in the main crop by obstructing or closing off a passage to the main crop. However, Boiteau et al. (2009) found that the height of the crop border did not make a difference in the number of aphids landing on the edge or border crop and the centre of the potato plot. Trap crops have been defined as crops that are attractive to the pest insect and therefore actively draw it away from the main crop, where it can be controlled by other means such as pesticides (Hokkanen 1991). The use of trap crops has been suggested to improve the effect of the border by increasing the number of alighting aphids (Hooks and Fereres 2006; Nault et al. 2004).

\section{Aphid host plant selection behaviour}

Aphids vary in their host plant specificity, ranging from one to a number of plant families, with pest species usually having a wider host range than species of little economic importance (Blackman and Eastop 2000). For example, $M$. persicae and $R$. padi, vectors of non-persistent viruses such as PVY, CMV and BYDV (Blackman and Eastop 2000; Bradley 1954; Katis and Gibson 1985; Raccah et al. 1985), are species with a wide host range. $M$. persicae feeds on numerous plant families including many crop species of economic importance in the family Solanaceae (Blackman and Eastop 2000 ). $R$. padi is oligophagous, feeding on many species of Poaceae, which include all the major cereals and pasture crops, but has also been recorded on Cyperaceae, Iridaceae, Juncaceae and Typhaceae (Blackman and Eastop 2000 ). The ability to locate a host plant may differ between aphid species due to their host ranges being different, and oligophagous species may use host plant cues in a different manner than polyphagous species (Hori 1999).

To locate their host plants, aphids rely on sensory information, such as colour, shape, texture and odour that they perceive from their environment (Bruce et al. 2005 ). This information is gathered in a number of consecutive behavioural steps and integrated within the central nervous system (Bruce and 
Pickett 2011; Bruce et al. 2005; Powell et al. 2006). The correct combination of plant characteristics will arrest aphids, and reproduction starts shortly after settling (Bruce et al. 2005). However, aphids are able to reject a plant at any one of these consecutive behavioural steps and continue searching for a new host plant (Powell et al. 2006).

After landing, and before stylet penetration, aphids evaluate plant surface characteristics (Powell et al. 2006). The chemical cues in the plant boundary layer, trichomes, epicuticular waxes, substrate topology and colour, may influence their behaviour (Goffreda et al. 1989; Ibbotson and Kennedy 1959; Powell et al. 1999; Storer et al. 1996). Although aphids probe leaves and other surfaces as a tarsal contact reflex, they may probe host and non-host plants alike shortly after landing, before further plant evaluation commences (Phelan and Miller 1982; Powell et al. 1999, 2006). Stylet penetration starts as brief probes to the epidermal layer during which small amounts of leaf sap are ingested (McLean and Kinsey 1968; Tjallingii 1985; Tjallingii and Esch 1993 ) and evaluated (Powell and Hardie 2000; Wensler and Filshie 1969). This is followed by longer probes (40-60 s) to the mesophyll and parenchyma tissue and ends in penetration of the phloem sieve element (Tjallingii and Esch 1993 ). However, aphids do not always penetrate the phloem sieve element while probing. McLean and Kinsey (1968) found that Acyrthosiphon pisum did not ingest phloem sap when penetrating the leaf tissue of a non-host plant. Winged aphids may also ingest xylem shortly after plant contact has been made (Powell and Hardie 2002). Therefore, aphids may alight in search of another plant shortly after initial probing to the epidermis has taken place.

The restless manner in which aphids land and settle on their host plants may play an important role in virus spread. Aphids perform several bouts of landing and taking off before settling and reproducing on a host plant (Kennedy and Booth 1963; Kennedy et al. 1959; Orlob 1961). The habit of settling and probing plants directly after landing (Powell 1991; Powell et al. 1992 , 2006) increases the risk of virus spread if an aphid lands on a virusinfected plant. Therefore, virus management strategies should target the pre-alighting phase of host plant selection behaviour to reduce the number of viruliferous aphids making contact with the crop plant. A detailed understanding of the interactions between aphid vector species, potential host plants and the virus involved, in the agro-ecosystem to be managed is important. 


\section{Non-persistent virus management strategies: the role of plant visual cues in aphid host plant selection behaviour}

Phototactic cues are involved in the initial phase of aphid host plant selection behaviour. Prior to landing, aphids are attracted to short wavelength light that causes them to fly skywards (Hardie 1989; Kennedy and Booth 1963).

However, in the alighting phase following the migratory flight, aphids become responsive to targets, such as colour cards, traps or plants (Hardie 1989; Kring 1967). During the alighting phase, aphids also become less sensitive towards short wavelength light, which causes them to move downwards towards the plant canopy. At the same time, they become more sensitive to long wavelength light between 500 and $600 \mathrm{~nm}$ that is typically reflected by plant foliage and yellow targets (Hardie 1989). This behavioural switch does not happen instantly but gradually, causing aphids to alight and take off several times before being ready to settle on a plant (Kennedy et al. 1961).

To enable humans to better interpret aphid colour preference based on a human colour naming system, Döring et al. (2009) developed a colour choice model based on testing 70 different colours in the field and taking both aphid and human photoreceptor characteristics into account. The model suggested that aphids are attracted to yellow, with a tendency to avoid red. This confirms the findings of many studies on aphid colour vision that aphids are generally attracted to yellow (Döring and Chittka 2007). However, species-specific differences in aphid colour preference for different hues and tints have been found; A. fabae landed more frequently on saturated yellow cards, whereas Hyalopterus pruni (Geoffroy) preferred unsaturated yellow cards (Moericke 1969).

In addition to hue and saturation, the achromatic aspects-of colour, light intensity plays an important role in aphid colour preference and may explain the sensitivity towards yellow found in many aphid species (Eastop 1955; Moericke 1969; Roach and Agee 1972). Döring and Chittka (2007) argued that the yellow preference found in aphids should not be viewed as a true colour preference but rather a response that is dependent on the actual light intensity. It may further be due to yellow representing a supernormal foliage stimulus to herbivorous insects rather than it being an ecological adaptation (Prokopy and Owens 1983).

A better understanding of the role of visual stimuli in aphid host plant selection behaviour could lead to improved management of aphid-transmitted 
plant viruses, e.g. choice of trap colour for aphid monitoring in crops and use of light reflectance (Döring and Chittka 2007). Yellow traps are frequently used for aphid monitoring, but not all species are equally sensitive to yellow (Broadbent 1948; Eastop 1955; Heathcote 1957; Roach and Agee 1972). This could lead to skewed results where the abundance of yellow-sensitive species is overestimated and that of species less sensitive to yellow is underestimated. This can be overcome by using a trap with the same wavelength reflectance spectra as the plant canopy. Irwin et al. (1988) found that a lime green tile trap with a wavelength reflectance closely resembling that of soybean crops correctly estimated aphid landing patterns compared to direct plant counts. However, when the same trap was used in pepper plants, the abundance of aphid species colonizing pepper was overestimated (Raccah et al. 1985 ). This shows that not only the wavelength reflectance of the plants is important but also the spectral reflectance behaviour of the aphids expected to be captured when developing traps for aphid monitoring.

Management tools such as reflective mulches that rely on aphid vision can effectively reduce non-persistent viruses (Antignus 2000; Döring and Chittka 2007). Silver reflective mulches delayed the onset of CMV, WMV-1 and WMV-2, ZYMV and Squash mosaic virus (SqMV) in summer squash (Cucurbito pepo L., Cucurbitaceae) and muskmelon (Brown et al. 1993; Stapleton and Summers 2002). The percentage coverage of the reflective covers was found to play a role in the reduction in virus incidence. Rows with complete coverage of reflective mulches were more effective than rows with partial coverage and alternate row applications (Stapleton and Summers 2002 ). Although reflective mulches increased yield and delayed virus infection in pumpkin, the effectiveness of the mulches decreased towards the end of the season (Brust 2000). Other methods that rely on manipulating aphid wavelength-dependent behaviour include covering the crop with reflective course nets, using greenhouses covered in photoselective (UV absorbing) plastic or nets, and spraying the crop with reflective materials, such as $15 \%$ whitewash (Antignus 2000). Subsequent studies have shown that greenhouse covering with UV absorbing plastic or nets significantly reduce the number of aphids immigrating, landing and colonizing as well as the incidence of aphid-transmitted potyviruses (Díaz et al. 2006; Kumar and Poehling 2006; Legarrea et al. 2010). For a detailed review on these methods, see Antignus (2000) and Díaz and Fereres (2007). In addition, the use of coloured net covering to protect crops reduced the number of aphids landing and subsequently the incidence of aphid-transmitted viruses 
(Ben-Yakir et al. 2012). For example, pepper and tomato plants grown under yellow and pearl net covering had significantly lower number of aphids landing on them in comparison with black and red. In addition, a significant reduction in PVY and CMV incidence was observed (Ben-Yakir et al. 2012).

\section{Non-persistent virus management strategies: the role of plant volatile cues in aphid host plant selection behaviour}

Several studies have demonstrated the use of plant volatiles by aphids during host plant selection (Bruce et al. 2005; Pickett et al. 1992; Powell et al. 2006; Webster 2012). These studies indicate that aphids are able to respond to single compounds from their host plants (Pettersson 1970b; Pettersson et al. 1994), as well as to blends of compounds (Webster 2012). Aphids detect plant volatile compounds through olfactory sensory neurones in sensilla located on their antennae, which are subdivided into primary and secondary rhinaria. The primary rhinaria are able to detect plant volatile compounds as well as aphid alarm pheromone (Bromley and Anderson 1982), and their function does not seem to differ between morphs. The secondary rhinaria are involved in aphid sex and alarm pheromone detection and differ between morphs (Park and Hardie 2002; Pettersson 1970a).

In spite of the numerous studies that have demonstrated the importance of plant volatile cues in aphid host plant location, and their role in non-persistent virus spread, little progress has been made in using this information to develop virus management strategies. Aphid non-host plant volatiles have been shown to be repellent to aphids. Isothiocyanates, such as 3-butanyl isothiocyanate and 4-pentenyl isothiocyanate, identified from the non-host plant brussels sprouts (Brassica oleraceae L., Brassicaceae) and turnip (B. campestris Metz., Brassicaceae), repelled alate A. fabae and also appeared to mask attraction to the host plant V. faba (Nottingham et al. 1991). Therefore, it is possible that non-host compounds can be used in crop protection strategies to mask the odour of host plants, and potentially reduce the number of aphids landing in the crop. However, it is only over the past decade that advancement has been made in understanding context and species-specific aphid-plant interactions and, more recently, the interaction between viruses, plant volatiles and virus vectors. This may have contributed to the delay in using plant olfactory cues in the development of integrated virus management strategies. 
Plant volatile compounds are context specific, and an aphid can respond to a single compound in a different manner than when it is presented in a blend released by its host plant. Plant volatile blends released by plants in specific ratios may be pivotal in providing aphids with host plant-specific information (Bruce and Pickett 2011; Bruce et al. 2005 ; Campbell et al. 1993; Webster 2012 ) and this may have implications for developing virus management strategies that rely only on the use of a single compound. Three compounds, methyl salicylate, $(E)$-2-hexenal and $\beta$-caryophyllene, were identified from hop (Humulus lupulus L., Canabaceae), the host plant of Phorodon humuli (Schrank), and found to be electrophysiologically active (Campbell et al. 1993 ). When these compounds were tested in an olfactory bioassay, P. humuli was attracted to $(E)$-2-hexenal and $\beta$-caryophyllene alone. However, the natural blend was more attractive to $P$. humuli than $(E)$-2-hexenal alone, and when the blend was adjusted to a 1:1 ratio it was no longer attractive (Campbell et al. 1993). Another example is A. fabae, which is attracted to the volatile blend of its host plant V. faba (Nottingham et al. 1991).

Electrophysiological responses were demonstrated for each of 15 volatile compounds identified from V. faba (Webster et al. 2008). However, a negative behavioural response was observed for 10 out of the 15 previously identified compounds from $V$. faba when presented to A. fabae individually (Webster et al. 2010). When the compounds that resulted in a negative response were combined in a blend, with each compound at the concentration that elicited the most negative response, the blend was attractive to A. fabae (Webster et al. 2010 ). Thus, there is ample evidence emphasizing that plant volatile blends play a role in aphid vector-virus interactions (Eigenbrode et al. 2002).

Plant viruses are known to alter plant volatile emission in ways that attract aphids to virus-infected plants (Eigenbrode et al. 2002; Ngumbi et al. 2007). Eigenbrode et al. (2002) found that potatoes infected with the persistently transmitted Potato leaf roll virus (PLRV) produced almost double the amount of total volatiles than uninfected plants. Potatoes infected with the non-persistent viruses PVY and Potato virus X (PVX) released two compounds in higher concentrations than uninfected plants, whereas PLRV infection resulted in elevated levels of 14 compounds (Eigenbrode et al. 2002; Ngumbi et al. 2007). In addition, Eigenbrode et al. (2002) found that M. persicae, the principal vector of PLRV, was attracted by the volatile profile of potato plants infected with PLRV but not to plants infected with PVY or PVX. Similarly Mauck et al. (2010) demonstrated that cucumber (Cucurbita pepo L., Cucurbitaceae) plants infected with the non-persistent CMV released 
slightly elevated concentrations of plant volatiles in comparison with uninfected plants. However, in contrast to the findings of Eigenbrode et al. (2002), Mauck et al. (2010) found that two vectors of CMV, Aphis gossypii (Glover) and $M$. persicae, were more attracted to cucumber plants infected with CMV than uninfected plants. Although A. fabae and M. persicae were attracted to volatiles of infected cucumber plants, they did not settle and reproduce in large numbers on these plants, whereas PLRV-infected potatoes caused M. persicae to settle in high numbers (Mauck et al. 2010; Ngumbi et al. 2007 ). This difference has been attributed to the different transmission characteristics of the virus, i.e. persistent or non-persistent. Mauck et al. (2010) suggested that the odour profile of plants infected with non-persistent viruses mimic the odour profile of healthy plants to attract aphids, while being a poor host facilitates non-persistent virus spread by causing the aphid to leave the plant in search of a better host.

The switch from primary host in winter to secondary host in spring is mediated by olfactory signals (Glinwood and Pettersson 2000 ; Pettersson et al. 1994). Methyl salicylate has been identified from the primary host of $R$. padi, the bird cherry tree (Prunus padus L., Rosaceae), and plays an important role in $R$. padi host finding behaviour (Pettersson et al. 1994). The autumn morphs are attracted to methyl salicylate, whereas the spring migrants are repelled, causing them to leave the primary host plant in search of a secondary host (Glinwood and Pettersson 2000; Ninkovic et al. 2003; Pettersson 1970b; Pettersson et al. 1994). Glinwood and Pettersson (2000) found the change in host plant preference to be gradual, and taking place within $24 \mathrm{~h}$ after $R$. padi spring migrants have left the primary host. Despite this change being gradual, methyl salicylate significantly reduced immigration, settling and density of $R$. padi in cereal fields, indicating the potential for this compound, and repellents in general to be incorporated into novel crop protection strategies (Ninkovic et al. 2003; Pettersson et al. 1994). Further work is needed to determine whether using a compound associated with the primary host that is repellent to the spring alate morphs will reduce transmission of early season non-persistent virus.

Other volatile compounds, repellent to aphids, include those associated with herbivore feeding. These herbivore-induced volatile compounds may act as a signal of competition, or indicate the presence of natural enemies of aphids, resulting in a reduced settling response (Bernasconi et al. 1998; Dewhirst and Pickett 2010; Ninkovic et al. 2001 ). Density-related substances have been identified as plant volatile substances affecting aphid behaviour (Holopainen 2004; Pettersson et al. 1995 ). Specifically, 6-methyl-5-hepten-2- 
one (sulcatone),

6-methyl-5-hepten-2-ol (sulcatol) and 2-tridecanone are associated with high aphid infestations on wheat and barley plants, and with increased sensitivity of aphids to disturbances and increased mobility of flying aphids (Pettersson et al. 1995; Quiroz et al. 1997). Ninkovic et al. (2003) determined that these compounds significantly reduced $R$. padi immigration, leading to reduced populations in cereals. Using density-related substances to reduce the number of immigrating aphids in a field has potential to reduce virus incidence, but as for other repellents, it will be necessary to establish whether reducing aphid numbers leads to significant reduction in virus transmission.

\section{Conclusion}

Chemical control methods available for aphid population management are not always efficient in reducing virus incidence (Desbiez and Lecoq 1997; Perring et al. 1999; Radcliffe and Ragsdale 2002; Robert 1992; Tomlinson 1987 ). The manner in which non-persistent viruses are spread and the interaction between virus, plant and vector, enable rapid virus spread. To develop crop protection strategies,-based on manipulating aphid behaviour, it is important to study how aphids respond to plant visual and olfactory cues within the agro-ecosystem that is to be managed. Aphid species composition and vegetation may differ between countries and provinces within a country where agricultural activities are centred, and not all crops are equally suited for different climatic regions (DiFonzo et al. 1995; Katis et al. 2006). Very few studies aimed at developing control strategies based on manipulating aphid vector behaviour have taken aphid species-specific

interactions into account. Variation in spectral specificity and olfactory signals have been reported between aphid species and their host plants (Archetti and Leather 2005; Bruce et al. 2005), yet few studies have taken this into account when developing virus management tactics aimed at reducing viruliferous aphids landing in target crops. Furthermore, the virus has no autonomous dispersal mechanism and is dependent on the insect vector to infect new hosts (Antignus 2000). The virus is able to alter its host plant characteristics to be more attractive to the vector but causes a low settling and reproduction rate in the case of some non-persistent viruses (Mauck et al. 2010, 2014). It is therefore important to remember that plant cues potentially used by aphids to locate their host plant are context specific. 
The majority of virus management strategies aimed at disrupting aphid landing have not evaluated the pre-flight behaviour of aphid vectors towards the crop species involved, e.g. crop borders (Fereres 2000), or have only focused on manipulating spectral behaviour, e.g. the use of mulches (Stapleton and Summers 2002). A more robust management system may be developed by manipulating both spectral and olfactory behaviours of the aphid vector species involved. The attractiveness of different crop cultivars to $R$. padi, a vector of PVY, was evaluated in comparison with potato. The preference of alate $R$. padi towards visual and olfactory stimuli of different host and non-host crop cultivars did not concur with the landing frequency of $R$. padi on the same crop cultivars when whole plants were presented to the aphids (Schröder et al. 2014, 2015a, b). The discrepancy between the different studies suggests a synergistic or additive effect is involved in the integration of visual and olfactory plant stimuli when searching for a host plant. Although synergism of visual and olfactory host plant stimuli has been poorly studied in aphids, it has been observed in other insect species, for example in the myrid Lygus hesperus (Heteroptera) where visual cues were found to enhance olfactory cues (Blackmer and Canas 2005). However, for aphids the interaction between visual and olfactory cues has only been studied in the sexual morphs and not for host plant finding in the parthenogenetic spring and summer morphs (Hardie et al. 1996). It should also be considered that these visual and olfactory channels have different spatial (Döring 2014) and temporal (Glinwood and Pettersson 2000) efficiency gradients and it is unknown which of the two components is more important for aphids at varying spatial scales (Döring 2014). Further work should be aimed at disrupting aphid visual and olfactory signals at the species level during host plant location, to reduce the number of aphids landing in the crops and thus the potential for virus spread.

1. Management decisions should be based on a good understanding of the interactions between the environment, vector species, virus species and relevant crops being produced within the specific agro-ecosystem, rather than relying on general recommendations.

2. Knowledge on how the virus interacts with its host plant to promote its own dispersal can be used to develop olfactory traps, border crops, trap crops or push-pull systems. It could also be used to develop traps that make use of both visual and olfactory signals, such as adding an attractive odour to a yellow sticky trap or pan trap. 
3. Information on the synergistic or additive effects of visual and olfactory cues in aphid host plant searching behaviour can be used to combine management tactics that use either visual or olfactory signals to disrupt aphid host plant location so that the sum of the methods result in an increased efficiency to reduce virus spread.

\section{Acknowledgments}

The review was part of M. L. Schröder's PhD thesis that was undertaken at the University of Pretoria (UP) in collaboration with the Swedish University of Agricultural Sciences (SLU). The study was financially supported by Potatoes South Africa (PSA), the Technology and Human Resources for Industry Programme (THRIPP), the National Research Foundation (NRF) and the University of Pretoria.

\section{References}

Antignus Y (2000) Manipulation of wavelength-dependent behaviour of insects: an IPM tool to impede insects and restrict epidemics of insect-borne viruses. Virus Res 71:213-220. doi:10.1016/S0168-1702(00)00199-4

Archetti M, Leather SR (2005) A test of the coevolution theory of autumn colours: colour preference of Rhopalosiphum padi on Prunus padus. Oikos 110:339-343.

doi:10.1111/j.0030-1299.2005.13656.x

Ben-Yakir D, Antignus Y, Offir Y, Shahak Y (2012) Colored shading nets impede insect invasion and decrease the incidences of insect-transmitted viral diseases in vegetable crops. Entomol Exp Appl 144:249-257. doi:10.1111/j.1570-7458.2012.01293.x

Bernasconi ML, Turlings TCJ, Ambrosetti L, Bassetti P, Dorn S (1998) Herbivoreinduced emissions of maize volatiles repel the corn leaf aphid, Rhopalosiphum maidis. Entomol Exp Appl 87:133-142. doi:10.1046/j.1570-7458.1998.00315.x

Blackman RL, Eastop VF (2000) Aphids on the world's crops: an identification and information guide, 2nd edn. Wiley, New Jersey

Blackmer JL, Canas LA (2005) Visual cues enhance the response of Lygus hesperus (Heteroptera: Miridae) to volatiles from host plants. Environ Entomol 34:1524-1533. doi:10.1603/0046-225X 34.6.1524

Boiteau G, Singh RP (1982) Evaluation of mineral oil sprays for reduction of virus Y spread in potatoes. Am Potato J 59:253-262. doi:10.1007/bf02856561

Boiteau G, Singh RP (1999) Field assessment of imidacloprid to reduce the spread of PVY and PLRV in potato. Am J Potato Res 76:31-36. doi:10.1007/bf02853555

Boiteau G, King RR, Levesque D (1985) Lethal and sublethal effects of Aldicarb on two potato aphids (Homoptera: Aphidae): Myzus persicae (Sulzer) and Macrosiphum 
euphorbiae (Thomas). J Econ Entomol 78:41-44. doi:10.1603/0046-225X-34.6.1524

Boiteau G, Singh M, Lavoie J (2009) Crop border and mineral oil sprays used in combination as physical control methods of the aphid-transmitted potato virus $\mathrm{Y}$ in potato. Pest Manag Sci 65:255-259. doi:10.1002/ps.1679

Boquel S, Ameline A, Giordanengo P (2011) Assessing aphids Potato virus Y-transmission efficiency: a new approach. J Virol Methods 178:63-67.

doi:10.1016/j.jviromet.2011.08.013

Boquel S, Giguère M-A, Clark C, Nanayakkara U, Zhang J, Pelletier Y (2013) Effect of mineral oil on Potato virus $\mathrm{Y}$ acquisition by

Rhopalosiphum padi. Entomol Exp Appl 148:48-55. doi:10.1111/eea.12070

Boquel S, Zhang J, Goyer C, Giguère M-A, Clark C, Pelletier Y (2015) Effect of insecticide-treated potato plants on aphid behavior and potato virus $\mathrm{Y}$ acquisition. Pest Manag Sci 71:1106-1112. doi:10.1002/ps.3892

Bradley RHE (1954) Studies of the mechanism of transmission of Potato virus Y by the green peach aphid, Myzus persicae (Sulz.) (Homoptera: Aphidae). Can J Zoolog 32:64-73. doi:10.1139/z54-008

Bradley RHE (1963) Some ways in which a paraffin oil impedes aphid transmission of Potato virus Y. Can J Microbiol 9:369-380. doi:10.1139/m63-045

Broadbent L (1948) Aphis migration and the efficiency of the trapping method. Ann Appl Biol 35:379-394. doi:10.1111/j.1744-7348.1948.tb07382.x

Broadbent L, Tinsley TW, Buddin W, Roberts ET (1951) The spread of lettuce mosaic in the field. Ann Appl Biol 38:689-706. doi:10.1111/j.1744-7348.1951.tb07838.x

Bromley AK, Anderson M (1982) An electrophysiological study of olfaction in the aphid Nasanovia ribis-nigri. Entomol Exp Appl 32:101-110.

doi:10.1111/j.1570-7458.1982.tb03188.x

Brown JE, Dangler JM, Woods FM, Tilt KM, Henshaw MD, Griffey WA, West MS (1993) Delay in mosaic virus onset and aphid vector reduction in summer squash grown on reflective mulches. HortScience 28:895-896

Bruce TJA, Pickett JA (2011) Perception of plant volatile blends by herbivorous insectsfinding the right mix. Phytochemistry 72:1605-1611. doi:10.1016/j.phytochem.2011.04.011

Bruce TJA, Wadhams LJ, Woodcock CM (2005) Insect host location: a volatile situation. Trends Plant Sci 10:269-274. doi:10.1016/j.tplants.2005.04.003

Brust GE (2000) Reflective and black mulch increase yield in pumpkins under virus disease pressure. J Econ Entomol 93:828-833. doi:10.1603/0022-0493-93.3.828

Campbell CAM, Pettersson J, Pickett JA, Wadhams LJ, Woodcock CM (1993) Spring migration of damson-hop aphid, Phorodon humuli (Homoptera, Aphididae), and summer host plant-derived semiochemicals released on feeding. J Chem Ecol 19:1569-1576. doi:10.1007/BF00984897 
Damicone JP, Edelson JV, Sherwood JL, Myers LD, Motes JE (2007) Effects of border crops and intercrops on control of cucurbit virus diseases. Plant Dis 91:509-516. doi:10.1094/PDIS-91-5-0509

Dean GJ (1974) Effect of temperature on the cereal aphids Metopolophium dirhodum (Wlk.), Rhopalosiphum padi (L.) and Macrosiphum avenue (F.) (Hem., Aphididae). Bull Entomol Res 63:401-409. doi:10.1017/S0007485300040888

Desbiez C, Lecoq H (1997) Zucchini yellow mosaic virus. Plant Pathol 46:809-829. doi:10.1046/j.1365-3059.1997.d01-87.x

Dewhirst SY, Pickett JA (2010) Production of semiochemical and allelobiotic agents as a consequence of aphid feeding. Chemoecology 20:89-96. doi:10.1007/s00049-009-0032-8

Díaz BM, Fereres A (2007) Ultraviolet-blocking materials as a physical barrier to control insect pests and plant pathogens in protected crops.

Pest Technology 1:85-95. doi:10.1603/0022-0493-93.3.828

Díaz BM, Biurrún R, Moreno A, Nebreda M, Fereres A (2006) Impact of ultravioletblocking plastic films on insect vectors of virus diseases infesting crisp lettuce.

HortScience 41:711-716. doi:10.1603/0022-0493-93.3.828

DiFonzo CD, Ragsdale DW, Radcliffe EB (1995) Potato leafroll virus spread in differentially resistant potato cultivars under varying aphid densities. Am Potato J 72:119132. doi:10.1007/BF02987284

DiFonzo CD, Ragsdale DW, Radcliffe EB, Gudmestad NC, Secor GA (1996) Crop borders reduce potato virus $\mathrm{Y}$ incidence in seed potato. Ann Appl Biol 129:289-302. doi:10.1111/j.1744-7348.1996.tb05752.x

Dixon AFG (1971) The life-cycle and host preferences of the bird cherry-oat aphid, Rhopalosiphum padi L., and their bearing on the theories of host alternation in aphids. Ann Appl Biol 68:135-147. doi:10.1111/j.1744-7348.1971.tb06450.x

Dixon AFG (1977) Aphid ecology: life cycles, polymorphism, and population regulation. Annu Rev Ecol Syst 8:329-353. doi:10.2307/2096732

Dixon AFG, Glen DM (1971) Morph determination in the bird cherry-oat aphid, Rhopalosiphum padi L. Ann Appl Biol 68:11-21. doi:10.1111/j.1744-7348.1971.tb04633.x

Döring TF (2014) How aphids find their host plants, and how they don't. Ann Appl Biol 165:3-26. doi:10.1111/aab.12142

Döring TF, Chittka L (2007) Visual ecology of aphids - a critical review on the role of colours in host finding. Arthropod-Plant Interact 1:3-16. doi:10.1007/s11829-006-9000-1

Döring TF, Archetti M, Hardie J (2009) Autumn leaves seen through herbivore eyes. Proc Roy Soc B-Biol 276:121-127. doi:10.1098/rspb.2008.0858

Eastop VF (1955) Selection of aphid species by different kinds of insect traps. Nature 176:936. doi:10.1038/176936b0

Eigenbrode SD, Ding H, Shiel P, Berger PH (2002) Volatiles from potato plants infected with potato leafroll virus attract and arrest the virus vector, Myzus persicae (Homoptera: Aphididae). Proc R Soc B-Biol Sci 269:455-460. doi:10.1098/rspb.2001.1909 
Fereres A (2000) Barrier crops as a cultural control measure of

non-persistently transmitted aphid-borne viruses. Virus Res 71:221-231.

doi:10.1016/S0168-1702(00)00200-8

Fereres A, Moreno A (2009) Behavioural aspects influencing plant virus transmission by homopteran insects. Virus Res 141:158-168. doi:10.1016/j.virusres.2008.10.020

Fereres A, Raccah B (2015) Plant virus transmission by insects. J eLS. doi:10.1002/9780470015902.a0000760.pub3

Gibson RW, Rice AD, Sawicki RM (1982) Effects of the pyrethroid deltamethrin on the acquisition and inoculation of viruses by Myzus persicae. Ann Appl Biol 100:49-54.

doi:10.1111/j.1744-7348.1982.tb07190.x

Glinwood R, Pettersson J (2000) Host choice and host leaving in Rhopalosiphum padi (Hemiptera: Aphididae) emigrants and repellency of aphid colonies on the winter host. Bull Entomol Res 90:57-61. doi:10.1017/S0007485300000717

Goffreda JC, Mutschler MA, Avé DA, Tingey WM, Steffens JC (1989) Aphid deterrence by glucose esters in glandular trichome exudate of the wild tomato, Lycopersicon pennellii. J Chem Ecol 15:2135-2147. doi:10.1007/BF01207444

Halbert SE, Irwin ME, Goodman RM (1981) Alate aphid (Homoptera: Aphididae) species and their relative importance as field vectors of soybean mosaic virus. Ann Appl Biol 97:1-9.doi:10.1111/j.1744-7348.1981.tb02988.x

Hardie J (1989) Spectral specificity for targeted flight in the black bean aphid, Aphis fabae. J Insect Physiol 35:619-626. doi:10.1016/0022-1910(89)90124-8

Hardie J, Storer JR, Cook FJ, Campbell CAM, Wadhams LJ, Lilley R, Peace L (1996) Sex pheromone and visual trap interactions in mate location strategies and aggregation by host-alternating aphids in the field. Physiol Entomol 21:97-106.

doi:10.1111/j.1365-3032.1996.tb00841.x

Heathcote GD (1957) The comparison of yellow cylindrical, flat and water traps, and of johnson suction traps, for sampling aphids. Ann Appl Biol 45:133-139.

doi:10.1111/j.1744-7348.1957.tb00449.x

Hokkanen HMT (1991) Trap cropping in pest management. Annu Rev Entomol 36:119138. doi:10.1146/annurev.en.36.010191.001003

Holopainen JK (2004) Multiple functions of inducible plant volatiles. Trends Plant Sci 9:529-533. doi:10.1016/j.tplants.2004.09.006

Hooks CRR, Fereres A (2006) Protecting crops from non-persistently aphid-transmitted viruses: a review on the use of barrier plants as a management tool. Virus Res 120:1-16. doi:10.1016/j.virusres.2006.02.006

Hori M (1999) Role of host plant odors in the host finding behaviors of aphids. Appl Entomol Zool 34:293-298 
Ibbotson A, Kennedy JS (1959) Interaction between walking and probing in Aphis fabae Scop. J Exp Biol 36:377-390

Irwin ME, Thresh JM, Harrison BD (1988) Long-range aerial dispersal of cereal aphids as virus vectors in North America. Phylos Trans R Soc B 321:421-446

Kalleshwaraswamy CM, Krishna Kumar NK, Dinesh MR, Chandrashekar KN, Manjunatha M (2009) Evaluation of insecticides and oils on aphid vectors for the management of papaya ringspot virus (PRSV). Karnataka J Agric Sci 22:552-553

Katis N, Gibson RW (1985) Transmission of potato virus Y by cereal aphids. Potato Res 28:65-70. doi:10.1007/bf02357571

Katis NI, Tsitsipis JA, Lykouressis DP, Papapanayotou A, Margaritopoulos JT, Kokinis GM, Perdikis DCH, Manoussopoulos IN (2006) Transmission of Zucchini yellow mosaic virus by colonizing and non-colonizing aphids in Greece and new aphid species vectors of the virus. J Phytopathol 154:293-302. doi:10.1111/j.1439-0434.2006.01096.x

Kennedy JS, Booth CO (1963) Free flight of aphids in the laboratory. J Exp Biol 40:67-85

Kennedy JS, Booth CO, Kershaw WJS (1959) Host finding by aphids in the field II. Aphis fabae Scop. (Gynoparae) and Brevicoryne brassicae L.; with a re-appraisal of the role of host-finding behaviour in virus spread. Ann Appl Biol 47:424-444. doi:10.1111/j.1744-7348.1959.tb07277.x

Kennedy JS, Booth CO, Kershaw WJS (1961) Host finding by aphids in the field III. visual attraction. Ann Appl Biol 49:1-21. doi:10.1111/j.1744-7348.1961.tb03587.x

Kostiw M, Trojanowska E (2011) Impact of feeding time on PVY and NTN PVY transmission by Myzus Persicae (SULZ.). J Plant Prot Res 51:429-434. doi:10.2478/v10045-011-0071-3

Kring JB (1967) Alighting of aphids on colored cards in a flight chamber. J Econ Entomol 60:1207-1210

Kring JB (1972) Flight behavior of aphids. Annu Rev Entomol 17:461-492. doi:10.1146/annurev.en.17.010172.00233

Kumar P, Poehling H-M (2006) UV-blocking plastic films and nets influence vectors and virus transmission on greenhouse tomatoes in the humid tropics. Environ Entomol 35:1069-1082. doi:10.1603/0046-225x-35.4.1069

Leather SR (1993) Overwintering in six arable aphid pests: a review with particular relevance to pest management. J Appl Entomol 116:217-233. doi:10.1111/j.14390418.1993.tb01192.x

Legarrea S, Karnieli A, Fereres A, Weintraub PG (2010) Comparison of UV-absorbing nets in pepper crops: spectral properties, effects on plants and pest control. Photochem Photobiol 86:324-330.

doi:10.1111/j.1751-1097.2009.00657.x

Lowery DT, Boiteau G (1988) Effects of five insecticides on the probing, walking, and settling behavior of the green peach aphid and the buckthorn aphid (Homoptera: Aphididae) on potato. J Econ Entomol 81:208-214. doi:10.1093/jee/81.1.208 
Loxdale HD, Hardie JIM, Halbert S, Foottit R, Kidd NAC, Carter CI (1993) The relative importance of short-and long-range movement of flying aphids. Biol Rev 68:291-311.

doi:10.1111/j.1469-185X.1993.tb00998.x

Makkouk KM, Kumari SG (2001) Reduction of incidence of three persistently transmitted aphid-borne viruses affecting legume crops by ${ }^{\circledR}$ seed-treatment with the insecticide imidacloprid (Gaucho ). Crop Prot 20:433-437. doi:10.1016/S0261-2194(00)00169-1

Makkouk KM, Kumari SG (2009) Epidemiology and integrated management of persistently transmitted aphid-borne viruses of legume and cereal crops in West Asia and North Africa. Virus Res 141:209-218. doi:10.1016/j.virusres.2008.12.007

Mauck KE, De Moraes CM, Mescher MC (2010) Deceptive chemical signals induced by a plant virus attract insect vectors to inferior hosts. PNAS 107:3600-3605. doi:10.1073/pnas.0907191107

Mauck K, Bosque-Pérez NA, Eigenbrode SD, De Moraes CM, Mescher MC (2012) Transmission mechanisms shape pathogen effects on host-vector interactions: evidence from plant viruses. Funct Ecol 26:1162-1175. doi:10.1111/j.1365-2435.2012.02026.x

Mauck KE, De Moraes CM, Mescher MC (2014) Biochemical and physiological mechanisms underlying effects of cucumber mosaic virus on host-plant traits that mediate transmission by aphid vectors. Plant Cell Environ 37:1427-1439. doi:10.1111/pce.12249

McKenna CE, Stevens PS, Steven D (1995) Phytotoxicity to kiwifruit from sprays of mineral oil. In: III International Symposium on Kiwifruit 444. pp 779-784

McLean DL, Kinsey MG (1968) Probing behavior of the pea aphid, Acyrthosiphon pisum II. Comparisons of salivation and ingestion in host and non-host plant leaves. Ann Entomol Soc Am 61:730-739. doi:10.1093/aesa/61.3.730

Minks AK, Harrewijn P (1988) Aphids: their biology, natural enemies, and control, vol 2. Elsevier, Netherlands

Moericke V (1969) Host plant specific colour behaviour by Hyalopterus pruni (Aphididae). Entomol Exp Appl 12:524-534. doi:10.1007/bf00297083

Müller CB, Williams IS, Hardie J (2001) The role of nutrition, crowding and interspecific interactions in the development of winged aphids. Ecol Entomol 26:330340. doi:10.1046/j.1365-2311.2001.00321.x

Nault LR (1997) Arthropod transmission of plant viruses: a new synthesis. Ann Entomol Soc Am 90:521-541. doi:10.1093/aesa/90.5.521

Nault BA, Shah DA, Dillard HR, McFaul AC (2004) Seasonal and spatial dynamics of alate aphid dispersal in snap bean fields in proximity to alfalfa and implications for virus management. Environ Entomol 33:1593-1601. doi:10.1603/0046-225X-33.6.1593

Ng JCK, Falk BW (2006) Virus-vector interactions mediating nonpersistent and semipersistent transmission of plant viruses. Annu Rev Phytopathol 44:183-212. doi:10.1146/annurev.phyto.44.070505.143325 
Ng JCK, Perry KL (2004) Transmission of plant viruses by aphid vectors. Mol Plant Pathol 5:505-511. doi:10.1111/j.1364-3703.2004.00240.x

Ngumbi E, Eigenbrode SD, Bosque-Pérez NA, Ding H, Rodriguez A (2007) Myzus persicae is arrested more by blends than by individual compounds elevated in headspace of PLRV-infected potato. J Chem Ecol 33:1733-1747. doi:10.1007/s10886-007-9340-z

Ninkovic V, Al Abassi S, Pettersson J (2001) The influence of aphid- induced plant volatiles on ladybird beetle searching behavior. Biol Control 21:191-195. doi:10.1006/bcon.2001.0935

Ninkovic V, Ahmed E, Glinwood R, Pettersson J (2003) Effects of two types of semiochemical on population development of the bird cherry oat aphid Rhopalosiphum padi in a barley crop. Agric For Entomol 5:27-33. doi:10.1046/j.1461-9563.2003.00159.x

Nottingham SF, Hardie J, Dawson GW, Hick AJ, Pickett JA, Wadhams LJ, Woodcock CM (1991) Behavioral and electrophysiological responses of aphids to host and nonhost plant volatiles. J Chem Ecol 17:1231-1242. doi:10.1007/BF01402946

Olson KD, Badibanga TM, Radcliffe EB, Ragsdale DW (2005) Producers' use of crop borders for management of Potato virus Y (PVY) in seed potatoes. University of Minnesota, Department of Applied Economics, Minnesota

Orlob GB (1961) Host plant preference of cereal aphids in the field in relation to the ecology of barley yellow dwarf virus. Entomol Exp Appl 4:62-72. doi:10.1111/j.1570-7458.1961.tb00484.x

Paliwal Y, Comeau A (1984) Epidemiology of barley yellow dwarf virus in Ontario and Quebec in 1982 and 1983. Can Plant Dis Surv 64:21-23

Park KC, Hardie J (2002) Functional specialisation and polyphenism in aphid olfactory sensilla. J Insect Physiol 48:527-535. doi:10.1016/S0022-1910(02)00082-3

Parker WE, Collier RH, Ellis PR, Mead A, Chandler D, Blood Smyth JA, Tatchell GM (2002) Matching control options to a pest complex: the integrated pest management of aphids in sequentially-planted crops of outdoor lettuce. Crop Prot 21:235-248. doi:10.1016/S0261-2194(01)00090-4

Perring TM, Farrar CA (1993) Stimulation of growth and yield of virus- infected cantaloupe with pyrethroids. Plant Dis 77:1077-1080. doi:10.1094/PD-77-1077

Perring TM, Gruenhagen NM, Farrar CA (1999) Management of plant viral diseases through chemical control of insect vectors. Annu Rev Entomol 44:457-481. doi:10.1146/annurev.ento.44.1.457

Pettersson J (1970a) An aphid sex attractant. Entomol Scand 1:63-73. doi:10.1163/187631270X00357

Pettersson J (1970b) Studies on Rhopalosiphum padi (L.). I. laboratory studies on olfactometric responses to winter host Prunus padus L. Lantbrukshögskolans Ann 36:381399 
Pettersson J, Pickett JA, Pye BJ, Quiroz A, Smart LE, Wadhams LJ, Woodcock CM (1994) Winter host component reduces colonization by bird-cherry-oat aphid, Rhopalosiphum padi (L.) (Homoptera, Aphididae), and other aphids in cereal fields. J Chem Ecol 20:2565-2574. doi:10.1007/BF02036192

Pettersson J, Quiroz A, Stephansson D, Niemeyer HM (1995) Odour communication of Rhopalosiphum padi on grasses. Entomol Exp Appl 76:325-328.

doi:10.1111/j.1570-7458.1995.tb01976.x

Phelan PL, Miller JR (1982) Post landing behavior of alate Myzus persicae as altered by (E)- $\beta$-farnesene and three carboxylic acids. Entomol Exp Appl 32:46-53. doi:10.1111/j.1570-7458.1982.tb03180.x

Pickett JA, Wadhams LJ, Woodcock CM, Hardie J (1992) The chemical ecology of aphids. Annu Rev Entomol 37:67-90. doi:10.1146/annurev.en.37.010192.000435

Powell G (1991) Cell membrane punctures during epidermal penetrations by aphids: consequences for the transmission of two potyviruses. Ann Appl Biol 119:313-321. doi:10.1111/j.1744-7348.1991.tb04870.x

Powell G (1992) The effect of mineral oil on stylet activities and potato virus Y transmission by aphids. Entomol Exp Appl 63:237-242. doi:10.1111/j.1570-

7458.1992.tb01579.x

Powell G, Hardie J (2000) Host-selection behaviour by genetically identical aphids with different plant preferences. Physiol Entomol 25:54-62. doi:10.1046/j.1365-

3032.2000.00164.x

Powell G, Hardie J (2002) Xylem ingestion by winged aphids. Entomol Exp Appl 104:103-108. doi:10.1046/j.1570-7458.2002.00996.x

Powell G, Harrington R, Spiller NJ (1992) Stylet activities and potato virus Y vector efficiencies by the aphids Brachycaudus helichrysi and Drepanosiphum platanoidis. Entomol Exp Appl 62:293-300. doi:10.1111/j.1570-7458.1992.tb00670.x

Powell G, Maniar SP, Pickett JA, Hardie J (1999) Aphid responses to non-host epicuticular lipids. In: Simpson SJ, Mordue AJ, Hardie J (eds) Proceedings of the 10th International Symposium on Insect-Plant Relationships, vol 56., Series Entomologica Springer, Netherlands, pp 115-123

Powell G, Tosh CR, Hardie J (2006) Host plant selection by aphids: behavioral, evolutionary, and applied perspectives. Annu Rev Entomol 51:309-330. doi:10.1146/annurev.ento.51.110104.151107

Prokopy RJ, Owens ED (1983) Visual detection of plants by herbivorous insects. Annu Rev Entomol 28:337-364. doi:10.1146/annurev.en.28.010183.002005

Quiroz A, Pettersson J, Pickett JA, Wadhams LJ, Niemeyer HM (1997) Semiochemicals mediating spacing behavior of bird cherry-oat aphid, Rhopalosiphum padi feeding on cereals. J Chem Ecol 23:2599-2607. doi:10.1023/B:JOEC.0000006669.34845.0d 
Raccah B, Gal-On A, Eastop VF (1985) The role of flying aphid vectors in the transmission of cucumber mosaic virus and potato virus Y to peppers in Israel. Ann Appl Biol 106:451460. doi:10.1111/j.1744-7348.1985.tb03135.x

Radcliffe EB, Ragsdale DW (2002) Aphid-transmitted potato viruses: the importance of understanding vector biology. Am J Pototo Res 79:353-386. doi:10.1007/BF02870173

Roach SH, Agee HR (1972) Trap colors: preference of alate aphids. Environ Entomol $1: 797-798$

Robert Y (1992) Prospects for improving potato crop protection against aphid vectors. J Plant Pathol 98:37-45. doi:10.1007/bf01974470

Robert Y, Woodford JAT, Ducray-Bourdin DG (2000) Some epidemiological approaches to the control of aphid-borne virus diseases in seed potato crops in northern Europe. Virus Res 71:33-47. doi:10.1016/S0168-1702(00)00186-6

Roberts JMF, Hodgson CJ, Jackai LEN, Thottappilly G, Singh SR (1993)

Interaction between two synthetic pyrethroids and the spread of two non-persistent viruses in cowpea. Ann Appl Biol 122:57-67.

doi:10.1111/j.1744-7348.1993.tb04014.x

Sastry KS (2013) Methods of combating seed-transmitted virus diseases. Seed-borne plant virus diseases. Springer, New York, pp 185-284

Schröder ML, Glinwood R, Ignell R, Krüger K (2014) Visual cues and host-plant preference of the bird cherry-oat aphid, Rhopalosiphum padi (Hemiptera: Aphididae). Afr Entomol 22:428-436. doi:10.4001/003.022.0217

Schröder ML, Glinwood R, Ignell R, Krüger K (2015a) Landing preference and reproduction of Rhopalosiphum padi (Hemiptera: Aphididae) in the laboratory on three maize, potato, and wheat cultivars. J Insect Sci 15:63-69. doi:10.1093/jisesa/iev048

Schröder ML, Glinwood R, Webster B, Ignell R, Krüger K (2015b) Olfactory responses of Rhopalosiphum padi to three maize, potato, and wheat cultivars and the selection of prospective crop border plants. Entomol Exp Appl 157:241-253. doi:10.1111/eea.12359

Simons JN, Zitter TA (1980) Use of oils to control aphid-borne virusses. Plant Dis 64:542546

Simons JN, McLean DL, Kinsey MG (1977) Effects of mineral oil on probing behavior and transmission of stylet-borne viruses by Myzus persicae. J Econ Entomol 70:309-315. doi:10.1093/jee/70.3.309

Stapleton JJ, Summers CG (2002) Reflective mulches for management of aphids and aphid-borne virus diseases in late-season cantaloupe (Cucumis melo L. var. cantalupensis). Crop Prot 21:891-898.

doi:10.1016/S0261-2194(02)00055-8

Storer JR, Powell G, Hardie J (1996) Settling responses of aphids in air permeated with non-host plant volatiles. Entomol Exp Appl 80:76-78. doi:10.1111/j.15707458.1996.tb00889.x 
Swenson KG (1968) Role of aphids in the ecology of plant viruses. Annu Rev Phytopathol 6:351-374. doi:10.1146/annurev.py.06.090168.002031

Tjallingii WF (1985) Membrane potentials as an indication for plant cell penetration by aphid stylets. Entomol Exp Appl 38:187-193. doi:10.1111/j.1570-7458.1985.tb03517.x

Tjallingii WF, Esch TH (1993) Fine structure of aphid stylet routes in plant tissues in correlation with EPG signals. Physiol Entomol 18:317-328. doi:10.1111/j.13653032.1993.tb00604.x

Toba HH, Kishaba AN, Bohn GW, Hield H (1977) Protecting muskmelons against aphid-borne viruses. Phytopathology 67:1418-1423. doi:10.1094/Phyto-67-1418

Tomlinson JA (1987) Epidemiology and control of virus diseases of vegetables. Ann Appl Biol 110:661-681.

doi:10.1111/j.1744-7348.1987.tb04187.x

Webster B (2012) The role of olfaction in aphid host location. Physiol Entomol 37:10-18. doi:10.1111/j.1365-3032.2011.00791.x

Webster B, Bruce T, Dufour S, Birkemeyer C, Birkett M, Hardie J, Pickett J (2008) Identification of volatile compounds used in host location by the black bean aphid, Aphis fabae. J Chem Ecol 34:1153-1161. doi:10.1007/s10886-008-9510-7

Webster B, Bruce T, Pickett J, Hardie J (2010) Volatiles functioning as host cues in a blend become nonhost cues when presented alone to the black bean aphid. Anim Behav 79:451457. doi:10.1016/j.anbehav.2009.11.028

Weidemann HL (1988) Importance and control of potato virus $\mathrm{Y}^{\mathrm{N}}\left(\mathrm{PVY}^{\mathrm{N}}\right)$ in seed potato production. Potato Res 31:85-94. doi:10.1007/BF02360024

Wensler RJ, Filshie BK (1969) Gustatory sense organs in the food canal of aphids. J Morphol 129:473-491. doi:10.1002/jmor.1051290406

Whitfield AE, Falk BW, Rotenberg D (2015) Insect vector-mediated transmission of plant viruses. Virology 479-480:278-289. doi:10.1016/j.virol.2015.03.026

Williams CT, Wratten SD (1987) The winter development, reproduction and lifespan of viviparae of Sitobion avenae (F.) (Hemiptera: Aphididae) on wheat in England. Bull Entomol Res 77:19-34. doi:10.1017/S0007485300011494

Wisler GC, Duffus JE (2000) A century of plant virus management in the Salinas Valley of California, 'East of Eden'. Virus Res 71:161-169. doi:10.1016/S0168-1702(00)00196-9 